International Research Journal of Engineering, IT \& Scientific Research
Available online at https://sloap.org/journals/index.php/irjeis/
Vol. 8 No. 1, January 2022, pages: 17-26
ISSN: 2454-2261
https://doi.org/10.21744/irjeis.v8n1.2045

\title{
The Rice Sort Machine Design to Improve Rice Granules Quality
}

I Ketut Gde Juli Suarbawa ${ }^{\text {a }}$

\section{Article history:}

Submitted: 27 November 2021

Revised: 09 December 2021

Accepted: 18 January 2022

\section{Keywords:}

machine rice sort; manual rice sort; musculoskeletal complaints; quality rice; work productivity;

\begin{abstract}
\end{abstract}
To produce quality rice, improvement in rice production management must begin at the farmer level (on-farm) by using high-quality seeds and good plant maintenance. Good quality rice is rice grains that don't break or crumble. To urge good quality rice, rice producers usually sort it manually. This method leads to long work processes and low productivity. Efforts to beat this problem are by designing a rice sorting machine which will separate whole rice and broken rice so on lighten the workload, improve rice quality, and increase prices. The results of the study obtained that the look specifications of the rice sieving machine were a). The sieving capacity is 10 $\mathrm{kg}$ of rice, the most drive is an electrical motor of $0.25 \mathrm{HP}$, a V-belt transmission, and an angled iron frame. Machine dimensions: length $120 \mathrm{~cm}$, width $70 \mathrm{~cm}$ and height $90 \mathrm{~cm}$ ). Machine testing the standard of rice grains employing a sorting machine can improve the standard of rice grains by reducing the presence of broken rice (size $\mathrm{p}=0.30 \mathrm{~mm}$ and below) a mean of $0.2 \mathrm{~kg}$ for $10 \mathrm{~kg}$ of sorted rice or increasing the standard by $1.91 \%$. Machine testing from the ergonomic aspect.

International research journal of engineering, IT \& scientific research (C) 2022. This is an open access article under the CC BY-NC-ND license (https://creativecommons.org/licenses/by-nc-nd/4.0/).

\section{Corresponding author:}

I Ketut Gde Juli Suarbawa,

Lecturer of the Department of Mechanical Engineering at Bali State Polytechnic, Denpasar, Indonesia.

Email address: julisuarbawa@pnb.ac.id

${ }^{a}$ Lecturer of the Department of Mechanical Engineering at Bali State Polytechnic, Denpasar, Indonesia 


\section{Introduction}

In Indonesia, various forms of rice are sold at prices that adjust looking at the standard of the rice. Various factors that determine the standard of rice are shape, size, and aroma. Rice produced by milling is mostly still mixed with broken rice, so a sorting process is required to separate whole rice grains from broken rice. The quality of harvested dry grain (GKP) may also affect the standard of the rice produced, like the presence of yellow grains, contaminants, broken grains, decreased quality when stored or mixed with other varieties. In Indonesia, the standard of rice is best known supported the processing method, like mashed or milled rice, supported the degree of polishing like slip rice, supported regional origin like Cianjur rice, and supported the sort or group of types like IR rice. Rice varieties have different resistance to moisture stress. This resistance is thought of as crack resistance (Allidawati \& Kustianto, 1989). Supported SNI 6128:2008, good quality rice is that the size of the pinnacle of the rice grains, both healthy and defective, which have a size greater than or capable 0.75 parts of whole rice grains. the method of sorting rice grains is currently done manually to separate whole rice from broken rice during a sitting position on the ground, long working hours, causing a rise in fatigue, musculoskeletal complaints, and workload, which successively reduces work productivity. Work postured and dealing with conditions that aren't ergonomic can cause complaints like disorders of the system (Manuaba, 2007), cause postural strain which may be a static mechanical load for the muscles which ends up in muscle fatigue (Pheasant, 1991). In step with Adiputra (2002), ergonomic intervention in small-scale industries using ergonomic work equipment will reduce workload and subjective complaints significantly thereby increasing productivity. Several alternative solutions to the above problems through an ergonomics approach are (Manuaba, 2007), (1) improving the organization and work system; (2) fixed-use machine design; and (3) improving work posture. With improvements through ergonomics within the mixing process, namely employing a rice sorter machine model, it's expected to scale back workload, musculoskeletal complaints, and fatigue levels similarly as save energy use and shorten the working time (Camacho et al., 2007; Saruta et al., 2013; Yadnya et al., 2016).

Efforts to beat this problem are by designing a rice sorting machine that may separate whole rice and broken (broken) rice so it can speed up the work process, improve the standard of rice production and also increase selling prices. the planning of the rice sorting machine functions as a machine to separate whole rice from crushed rice through a sieving process that will separate whole rice from crushed rice. The sieving is intended in keeping with a specific grain size that may still have the sieve, which is expressed as crushed grain. the utilization of sorting technology in agriculture has been widely applied, for instance, the carambola sorting system (Abdullah et al., 2006), identification of the degree of harm to coffee beans (Sofi'i \& Astika, 2005), edamame cheese grading (Soedibyo et al., 2006), and cut flower grading (Ahmad et al., 2006).

\section{Materials and Methods}

\subsection{Research design}

This research is a one-short case study with a pre and post-test design group which was carried out observationally on the rice sorting work process (Corlett, 2005). The chart can be described as follows:

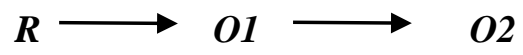

Description:

$\mathrm{R}=$ Random sample.

$\mathrm{O} 1=$ The results measured of the pretest experimental unit.

$\mathrm{O} 2=$ The results measured of the posttest experimental unit.

\subsection{Research variable}

The variables to be measured during this study include: (1). workload as measured by pulse before and after work; (2) complaints of fatigue and skeletal muscles before and after work; (3) work productivity after work by comparing work pulse (beats per minute) with the number of products produced (kg) during working time (minutes). The measurement of variables number (1) to number (3) is that the initial condition information data and also the final 
condition is then compared to work out the comparison before the utilization of the rice sorter machine and after the employment of the rice sorter machine (Salter \& Wyatt, 1991; Blasco et al., 2009; Van Soest, 2006).

\section{Results and Discussions}

\subsection{Rice sorting machine design}

The design concept of designing a rice sorting machine to improve the quality of rice grains is as follows:
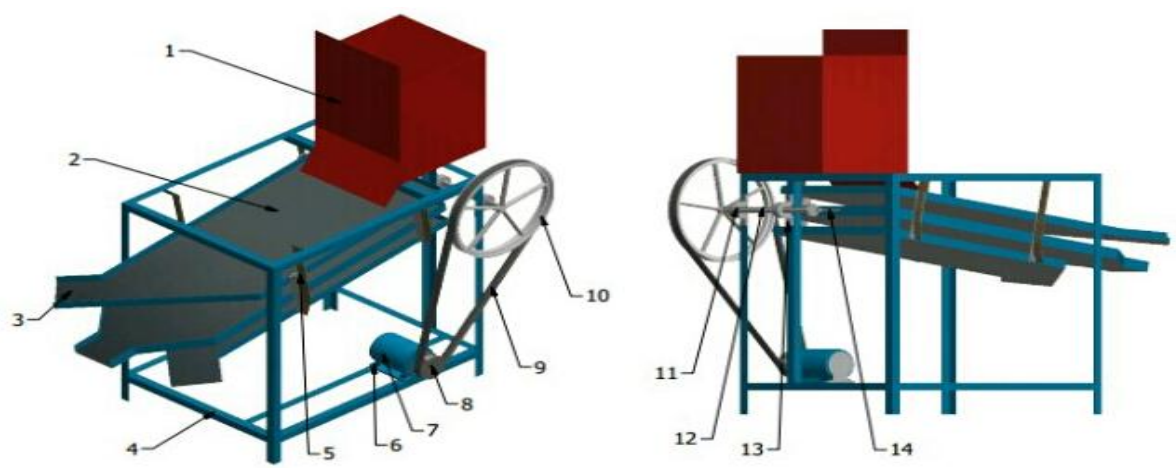

Figure 1. Design of rice sorting machine

Caption:

$\begin{array}{llll}\text { 1. } & \text { Rice Container } & 8 . & \text { Pully No. } 1 \\ \text { 2. } & \text { Sieve Wire } & 9 . & \text { V- Belt } \\ \text { 3. } & \text { Rice Outlet } & 10 . & \text { Pully No.2 } \\ \text { 4. } & \text { Main Frame } & 11 . & \text { Bearing House } \\ \text { 5. } & \text { Strength Van Belt } & 12 . & \text { Axis } \\ \text { 6. } & \text { Bolt } & 13 . & \text { Bearing House Bolt } \\ \text { 7. } & \text { Electric motor } & 14 . & \text { Sieve pendulum }\end{array}$

\subsection{The result of rice sorting machine design}

The results of the design of the rice sorting machine designed with an electric motor drive connected via a V-Belt to drive the complete sieve can be seen in Figure 2.

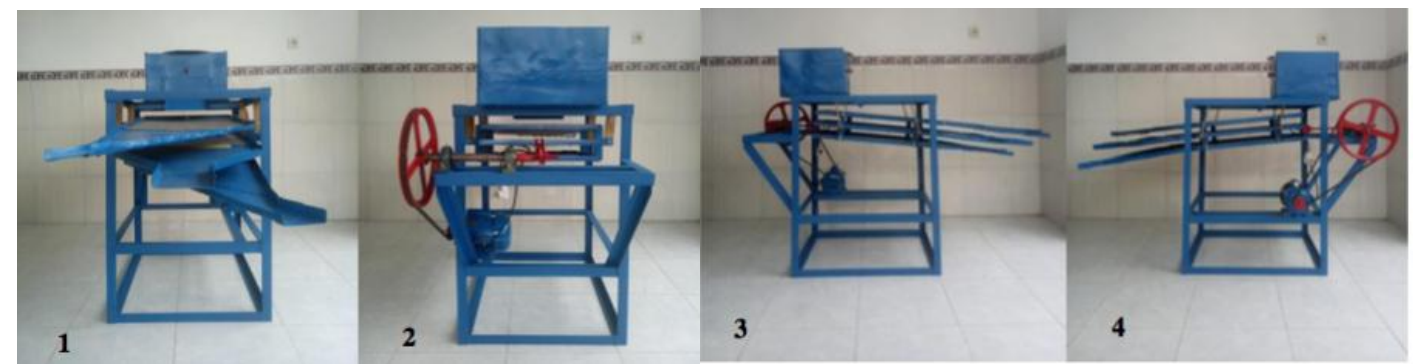

Figure 2. The results of rice sorting machine design (1. Back View, 2. Front View, 3. Right Side View, and 4. Left Side View)

Suarbawa, I. K. G. J. (2022). The rice sort machine design to improve rice granules quality. International Research Journal of Engineering, IT \& Scientific Research, 8(1), 17-26. 


\subsection{Machine specification}

The specifications of the machine designed using an electric motor drive HP with a capacity of $10 \mathrm{Kg}$ sieve, are fully presented as follows:
1) Capacity
: $10 \mathrm{Kg}$
2) Drive
: Electric Motor
3) Motor Power
: $1 / 4$ HP 1 Phase
4) Machine Dimension
: $(1580 \times 620 \times 1160) \mathrm{mm}$
5) Main Frame
: Angle iron bar, $(40 \times 40 \times 3) \mathrm{mm}$
6) Fastening Bolt
: Ø $12 \mathrm{~mm}$ and $\varnothing 14 \mathrm{~mm}$
7) Motor Pulley Diameter
: $6 \mathrm{~mm}$
8) Sieve Pulley Diameter
: $30 \mathrm{~mm}$
9) Transmission
: V-Belt Type A-63
10) Axis
11) Bearing
12) Machine Weight
: ST $37 \varnothing 25 \mathrm{~mm}$
: P 205; $\varnothing \mathrm{d}=25 \mathrm{~mm}$ and $\varnothing \mathrm{D}=52 \mathrm{~mm}$
$: 80 \mathrm{Kg}$

\subsection{Rice grain quality test}

The results of the manual large sorting test were administrated by separating whole rice and broken rice manually which was disbursed by 10 workers by sorting $10 \mathrm{~kg}$ of rice each. The rice that's sorted is rice that has been milled at one in every of the rice producers within the region. While the results of the rice sorting test were distributed 10 times sorting and every time the sorting was $10 \mathrm{Kg}$ of rice. The rice that's sorted employing a machine is the same rice, which is the result of rice production from one among the rice producers within the Bali area. the typical acceptable whole rice is Rice with Mesh $45(0.354 \mathrm{~mm})$ and Mesh $70(0.210 \mathrm{~mm})$ for manual sorting (Mohammed \& Tarpley, 2009; Fitzgerald et al., 2009). Sorting with the designed sorting machine is that the rice received is Mesh 45 $(0.354 \mathrm{~mm})$ and uses a $0.300 \mathrm{~mm}$ sieve so the $0.300 \mathrm{~mm}$ rice is separated or the rice grains received are Mesh 45 and Mesh 70 is wasted. The standard of rice because the output of the choice web that's made refers to SNI 6128: 2008 (BSN, 2008). The definition for every criterion of the extent of failure is presented in Table 1

Table 1

Definitions for each physical quality criterion of rice-based on SNI 6128: 2008

\begin{tabular}{|c|c|c|}
\hline No. & Physical quality & Definition \\
\hline 1 & Head grain & $\begin{array}{l}\text { Rice grains, both healthy and defective, have a size greater than or equal to } \\
0.75 \text { parts of whole rice grains. }\end{array}$ \\
\hline 2 & Broken grain & $\begin{array}{l}\text { Rice grains, both healthy and defective, have a size greater than } 0.25 \text { to } 0.75 \\
\text { smaller than whole rice grains. }\end{array}$ \\
\hline 3 & Groats & $\begin{array}{l}\text { Rice grains, both healthy and defective, have a size smaller than } 0.25 \text { parts of } \\
\text { whole rice grains. }\end{array}$ \\
\hline 4 & Grain * & Rice grains have been separated from the panicles. \\
\hline
\end{tabular}

The results of the manual rice sorting test conducted by 10 female workers and the sorting using a sorting machine are presented in Table 2.

Table 2

Test results of manual rice sorting and using a sorting machine

\begin{tabular}{|c|c|c|c|c|c|c|c|}
\hline \multirow[b]{2}{*}{ No. } & \multirow[b]{2}{*}{$\begin{array}{l}\text { Rice Sorting } \\
\text { Capacity (kg) }\end{array}$} & \multicolumn{3}{|c|}{ Manual Sorting } & \multicolumn{3}{|c|}{ With Rice Sorting Machine } \\
\hline & & $\begin{array}{l}\text { Working } \\
\text { Process } \\
\text { Time } \\
\text { (minutes) }\end{array}$ & $\begin{array}{l}\text { Rice sorting } \\
\text { results } \\
(\mathrm{p}=0,354 \mathrm{~mm}) \\
\text { in } \mathrm{Kg}\end{array}$ & $\begin{array}{l}\text { Rice sorting } \\
\text { results } \\
\mathrm{p}<=0,210 \text { in } \\
\mathrm{Kg}\end{array}$ & $\begin{array}{l}\text { Working } \\
\text { Process } \\
\text { Time } \\
\text { (minutes) }\end{array}$ & $\begin{array}{l}\text { Rice sorting } \\
\text { results } \\
(\mathrm{p}=0,354 \mathrm{~mm})\end{array}$ & $\begin{array}{l}\text { Rice sorting } \\
\text { results } \\
(<=0,30 \mathrm{~mm})\end{array}$ \\
\hline
\end{tabular}




\begin{tabular}{llllllll}
\hline 1 & 10 & 199 & 9,4 & 0,6 & 15 & 9,2 & 0,8 \\
2 & 10 & 196 & 9,3 & 0,7 & 14 & 9,2 & 0,8 \\
3 & 10 & 202 & 9,5 & 0,5 & 17 & 9,1 & 0,9 \\
4 & 10 & 205 & 9,5 & 0,5 & 14 & 9,3 & 0,7 \\
5 & 10 & 201 & 9,6 & 0,4 & 16 & 9,4 & 0,6 \\
6 & 10 & 203 & 9,3 & 0,7 & 15 & 9,1 & 0,9 \\
7 & 10 & 207 & 9,3 & 0,7 & 14 & 9,4 & 0,6 \\
8 & 10 & 208 & 9,2 & 0,8 & 17 & 9,3 & 0,7 \\
9 & 10 & 200 & 9,6 & 0,4 & 13 & 9,2 & 0,8 \\
10 & 10 & 212 & 9,4 & 0,6 & 15 & 9,1 & 0,9 \\
Average & 10 & 203 & 9,4 & 0,6 & 15 & 9,2 & 0,8 \\
\hline
\end{tabular}

Based on Table 2, it's found that the typical manual sorting time is 203 minutes while employing a machine is just a quarter-hour or reduces working time by $92.62 \%$. Rice grains received within the rice sorting process with the Sorting Machine are grain length $(0.350-0.354 \mathrm{~mm})$ which is a median of $9.2 \mathrm{Kg}$ for $10 \mathrm{Kg}$ of sorted rice. While within the manual sorting process, the scale of rice received is grain length $(0.210-0.354 \mathrm{~mm}) \mathrm{which}$ is $9.4 \mathrm{~kg}$ on average for $10 \mathrm{~kg}$ of sorted rice. employing a sorting machine can improve the standard of rice grains by reducing the presence of broken rice (size $\mathrm{p}=0.30 \mathrm{~mm}$ and below) by a median of $0.2 \mathrm{~kg}$ for $10 \mathrm{Kg}$ of sorted rice or increasing the standard of rice by $1.91 \%$.

\subsection{Ergonomic aspect test used rice sorting machine design \\ 3.5.1 Workload}

Measurement of workload is applied by measuring the work pulse per minute with the ten beats method. The working pulse is measured every hour. the ten beats method could be a method by palpating the arterial blood vessel of the hand, which is calculated because of the length of your time it takes from the primary felt pulse to the eleventh pulse, the result's in seconds (Adiputra, 2002). The workload was measured in Period I (P0) research, namely research on the manual sorting process of rice, and in Period II (PI) research, namely the sorting process employing a rice sorting machine. the employment of a rice sorting machine within the rice sorting process reduces the workload of workers by $48 \%$. the common working rate of workers within the P0 study (sorting manually) was $93.13 \mathrm{bpm}$ including the category of sunshine workload (pulse 75-100) while the common working pulse of workers within the P1 study (sorting employing a rice sorting machine) obtained the typical heart rate work of $73.95 \mathrm{bpm}$, including the category of very light workload (pulse 65-75) (Adiputra, 2002).

Table 3

Results of rice sorting process load measurement

\begin{tabular}{|c|c|c|c|c|c|c|c|c|c|}
\hline \multirow[b]{2}{*}{ No. } & \multirow[b]{2}{*}{ Description } & \multicolumn{4}{|c|}{ Period I (P0) } & \multicolumn{4}{|c|}{ Period II (PI) } \\
\hline & & Mini-mum & Maxi-mum & Average & $\begin{array}{l}\text { Standard } \\
\text { Deviation }\end{array}$ & Mini-mum & Maxi-mum & Average & $\begin{array}{l}\text { Standard } \\
\text { Deviation }\end{array}$ \\
\hline 1. & $\begin{array}{l}\text { Resting } \\
\text { Pulse (bpm) }\end{array}$ & 65.12 & 72.50 & 70.16 & 3,25 & 61.92 & 71.82 & 70.40 & 3.41 \\
\hline 2. & $\begin{array}{l}\text { Work Pulse } \\
\text { (bpm) }\end{array}$ & 81.52 & 95.53 & 93.13 & 4.03 & 70.78 & 83.16 & 73.95 & 3.91 \\
\hline 3. & $\begin{array}{l}\text { Increased } \\
\text { Pulse (bpm) }\end{array}$ & 19.41 & 22.72 & 20.51 & 3,40 & 9.46 & 13.20 & 11.11 & 3.05 \\
\hline
\end{tabular}

\subsubsection{Fatigue and musculoskeletal complaints}

The subject's musculoskeletal complaints were measured employing a Nordic Body Map (NBM) questionnaire before and after-work activities. The validity of the questionnaire has been tested with the results showing that every one item is valid ( $\mathrm{r}$ count $>\mathrm{r}$ table) where the $\mathrm{r}$ table at $=5 \%$ is 0.458 or significance $<0.05$, while the reliability of the questionnaire obtained Cronbach's Alpha value $=0.755$ (above 0.6). that the questionnaire is valid and reliable (Xie et al., 2017; Gallagher, 2005; Suriani, 2019). The results of measuring musculoskeletal complaints within the manual rice sorting work process (PI) obtained a mean score before work of $28.16 \pm 0.69$ and after work, it increased

Suarbawa, I. K. G. J. (2022). The rice sort machine design to improve rice granules quality. International Research Journal of Engineering, IT \& Scientific Research, 8(1), 17-26. 
to $41.34( \pm 3.98)$ or experienced a rise in the score of $13.18( \pm 3.42)$. The results of measurements on the work process of sorting rice employing a machine (PII) obtained a median score of musculoskeletal complaints before work of $30.62( \pm 0.90)$ and after work, it increased to $37.31( \pm 3.08)$ or increased by $6.54( \pm 1.72)$. The common score of fatigue complaints before manual rice sorting work (PI) was $30.80( \pm 1.40)$ increased to $39.10( \pm 3.06)$ after work or a rise in score was $8.29( \pm 3.19)$. the typical score of fatigue complaints before work on the rice sorting work process employing a machine (PII) was $30.95( \pm 1.08)$, increased to $36.10( \pm 2.06)$ after work, or experienced a rise in the score of $5.7( \pm 0.99)$.

The increase within the average score for musculoskeletal complaints and complaints of fatigue was because of a bent work posture within the rice sorting process. Work posture that bends over and over for an extended time may be a work posture that's not physiological. Work postures that don't seem to be physiological are often caused by the characteristics of task demands, work tools, work stations, and work postures that don't seem to be in by the skills and limitations of workers (Manuaba, 2007; Grandjean \& Kroemer, 1997). Un-physiological work postures that are administrated for years can cause bone abnormalities in workers (Grandjean \& Kroemer, 1997).

Table 4

Measurement results of increased fatigue and musculoskeletal complaints

\begin{tabular}{|c|c|c|c|c|c|c|c|c|c|}
\hline \multirow[b]{2}{*}{ No. } & \multirow[b]{2}{*}{ Description } & \multicolumn{4}{|c|}{ Period I (P0) } & \multicolumn{4}{|c|}{ Period II (PI) } \\
\hline & & Mini-mum & Maxi-mum & Average & $\begin{array}{l}\text { Standard } \\
\text { Deviation }\end{array}$ & Mini-mum & Maxi-mum & Average & $\begin{array}{l}\text { Standard } \\
\text { Deviation }\end{array}$ \\
\hline 1 & $\begin{array}{l}\text { The increased } \\
\text { fatigue score } \\
\text { before and after } \\
\text { work }\end{array}$ & 6 & 12 & 8.29 & 3.19 & 4.31 & 6.43 & 5.7 & 0.99 \\
\hline 2. & $\begin{array}{l}\text { The increased } \\
\text { score of } \\
\text { musculoskeletal } \\
\text { complaints before } \\
\text { and after work }\end{array}$ & 12 & 17 & 13.18 & 3.42 & 3.31 & 11.25 & 6.54 & 1.72 \\
\hline
\end{tabular}

Kimberly (2011), states that it's necessary to alter the work system to cut back the amount of worker fatigue (Kimberly, 2011). Roles et al. (2009), conducted a study on a piece model that supported ergonomics and located that the work model was able to reduce fatigue up to $17.71 \%$. Husein et al. (2009), also stated that the planning of an ergonomics work system can reduce the extent of worker fatigue. While Dinata et al. (2015), researched alternative working postures sitting and standing can reduce work fatigue up to $11.79 \%$. The working posture of craftsmen should be cultivated in physiological positions like when sitting and standing, to not cause work postures that pass through the body's physiological abilities (Grandjean \& Kroemer, 1997). This is often by the research conducted by Putri \& Griadhi (2015), which states that improving ergonomic working conditions can reduce workers' musculoskeletal complaints.

\subsubsection{Work productivity}

The work productivity of the themes within the rice sorting process was recorded supported the comparison of output (output) with input (input) at a particular unit of time. The output produced is the amount of sorted rice produced by the crafter during working hours, while the input is the working pulse of the crafter. The calculation results of manual rice sorting work productivity (PI) is $54.21 \pm 3.09$ and rice sorting work productivity employing a sorting machine (PII) is $133.69 \pm 1.49$ and a rise of $146.61 \%$. This increase in productivity is because of a decrease in workload and reduced fatigue and musculoskeletal complaints similar to a rise within the production of rice sorts. To extend productivity, consistent with Kimberly (2011), it's necessary to alter the work system to scale back the amount of worker fatigue so that working time is shorter and production can increase (Kimberly, 2011). Husein et al. (2009), also stated that the planning of an ergonomic work system can reduce the amount of worker fatigue. 
Table 5

Results of work productivity measurement

\begin{tabular}{lccccc}
\hline & $\mathrm{n}$ & Minimum & Maximum & Mean & Std. Deviation \\
\hline $\begin{array}{l}\text { Work productivity using a } \\
\text { sorting machine }\end{array}$ & 10 & 99 & 152 & 133.69 & 1.49 \\
$\begin{array}{l}\text { Productivity of manual } \\
\text { sorting }\end{array}$ & 10 & 49 & 60 & 54.21 & 3.09 \\
\hline
\end{tabular}

Ergonomics intervention recommendations to extend work productivity also are widely stated by ergonomics researchers, like in Priambadi's (2013), research through improving working conditions for smelting gamelan craftsmen can increase work productivity by $26.67 \%$ and Susana's (2018), research with Ergonomics intervention can increase work productivity by $54.88 \%$. Setiawan's (2014), research through work station design can increase work productivity by 20.29\%. The research of Yusuf et al. (2018), and Suarbawa et al. (2018), research also states that non-physiological work postured can cause a rise in musculoskeletal complaints and worker fatigue.

\section{Conclusion}

Based on the discussion that has been carried out, the following conclusions can be:

1) The planning specifications of the rice sieving machine are: the sieving capacity is $10 \mathrm{~kg}$ of rice, with an electrical motor of $0.25 \mathrm{HP}$, a V-belt transmission, and an angled iron frame. Machine dimensions: length 120 $\mathrm{cm}$, width $70 \mathrm{~cm}$ and height $90 \mathrm{~cm}$.

2) Rice quality testing shows that employing a sorting machine can improve the standard of rice grains by reducing the presence of broken rice (size $\mathrm{p}=0.30 \mathrm{~mm}$ and below) by a median of $0.2 \mathrm{~kg}$ for $10 \mathrm{Kg}$ of sorted rice or increasing the standard of rice by $1,91 \%$.

3) Machine testing from the ergonomic aspect, among others:

a) The employment of a rice sorting machine within the rice sorting process reduces the workload of workers by $48 \%$. the typical working vital sign of workers within the P0 study (sorting manually) was $93.13 \mathrm{bpm}$ including the category of sunshine workload (pulse 75-100) while the typical working pulse of workers within the P1 study (sorting employing a rice sorting machine) was obtained the common vital sign work of $73.95 \mathrm{bpm}$, including the very light workload category.

b) The results of measuring musculoskeletal complaints within the manual rice sorting work process (PI) obtained a median score before work of $28.16 \pm 0.69$ and after work, it increased to 41.34 ( \pm 3.98$)$ or experienced a rise in the score of $13.18( \pm 3.42)$. The results of measurements on the work process of sorting rice employing a machine (PII) obtained a mean score of musculoskeletal complaints before work of $30.62( \pm 0.90)$ and after work, it increased to $37.31( \pm 3.08)$ or increased by $6.54( \pm 1.72)$.

c) The typical score of fatigue complaints before manual rice sorting work (PI) was $30.80( \pm 1.40)$ increased to $39.10( \pm 3.06)$ after work or a rise in score was $8.29( \pm 3.19)$. the common score of fatigue complaints before work on the rice sorting work process employing a machine (PII) was $30.95( \pm 1.08)$, increased to $36.10( \pm 2.06)$ after work, or experienced a rise in the score of $5.7( \pm 0.99)$.

d) The calculation results of manual rice sorting work productivity (PI) is $54.21 \pm 3.09$ and rice sorting work productivity employing a sorting machine (PII) is $133.69 \pm 1.49$ and a rise of $146.61 \%$.

Conflict of interest statement

The author declared that he have no competing interest.

Statement of authorship

The author have a responsibility for the conception and design of the study. The author have approved the final article.

Suarbawa, I. K. G. J. (2022). The rice sort machine design to improve rice granules quality. International Research Journal of Engineering, IT \& Scientific Research, 8(1), 17-26.

https://doi.org/10.21744/irjeis.v8n1.2045 
Acknowledgments

I am grateful to two anonymous reviewers for their valuable comments on the earlier version of this paper. 


\section{References}

Abdullah, M. Z., Mohamad-Saleh, J., Fathinul-Syahir, A. S., \& Mohd-Azemi, B. M. N. (2006). Discrimination and classification of fresh-cut starfruits (Averrhoa carambola L.) using automated machine vision system. Journal of Food Engineering, 76(4), 506-523. https://doi.org/10.1016/j.jfoodeng.2005.05.053

Adiputra, N. (2002). Pulse Rate and Its Use in Ergonomics. Indones. J. Ergon, 3(1), 1-6.

Ahmad, U., Syaefullah, E., \& Purwadaria, H. K. (2006). Valuasi Mutu Bunga Potong Krisan Yellow Fiji Menggunakan Pengolahan Citra. Jurnal Keteknikan Pertanian, 20(3).

Allidawati \& B. Kustianto. (1989). Rice quality test method in rice breeding program. Paddy Book 2. Agricultural Research and Development Agency. Center for Food Crops Research and Development. Bogor. Hal: 363-375, 1989.

Blasco, J., Cubero, S., Gómez-Sanchís, J., Mira, P., \& Moltó, E. (2009). Development of a machine for the automatic sorting of pomegranate (Punica granatum) arils based on computer vision. Journal of food engineering, 90(1), 2734. https://doi.org/10.1016/j.jfoodeng.2008.05.035

Camacho, J., Lewis, R., \& Dwyer-Joyce, R. S. (2007). Wear of a chute in a rice sorting machine. Wear, 263(1-6), 6573. https://doi.org/10.1016/j.wear.2006.11.052

Corlett, E. N. (2005). Static muscle loading and the evaluation of posture. Evaluation of human work, $453-496$.

Dinata, I. M. K., Adiputra, N., \& Adiatmika, I. P. G. (2015). Alternating sitting-standing posture decrease fatigue, musculoskeletal complaint and increase productivity of ironing women worker in household. Journal Ergonomi Indonesia, 1(1), 30-40.

Fitzgerald, M. A., McCouch, S. R., \& Hall, R. D. (2009). Not just a grain of rice: the quest for quality. Trends in plant science, 14(3), 133-139. https://doi.org/10.1016/j.tplants.2008.12.004

Gallagher, S. (2005). Physical limitations and musculoskeletal complaints associated with work in unusual or restricted postures: a literature review. Journal of Safety Research,36(1), 51-61. https://doi.org/10.1016/j.jsr.2004.12.001

Grandjean, E., \& Kroemer, K. H. (1997). Fitting the task to the human: a textbook of occupational ergonomics. CRC press.

Husein, T., Kholil, M., \& Sarsono, A. (2009). Perancangan sistem kerja ergonomis untuk mengurangi tingkat kelelahan. Inasea, 10(1), 45-58.

Kimberly, F.K. (2011). Effect of Shift Work on Fatigue of Palm Oil Mill Workers at PT. X Labuhan Batu. Journal of Industrial Engineering, Vol. 12, No. 2, Agustus 2011. p110-117.

Manuaba, A. (2007). A total approach in ergonomics is a must to attain humane, competitive and sustainable work systems and products. Journal of human ergology, 36(2), 23-30.

Mohammed, A. R., \& Tarpley, L. (2009). High nighttime temperatures affect rice productivity through altered pollen germination and spikelet fertility. Agricultural and Forest Meteorology, 149(6-7), 999-1008. https://doi.org/10.1016/j.agrformet.2008.12.003

Pheasant, S. (1991). Ergonomics, work and health. Macmillan International Higher Education.

Priambadi, I. G. N. (2013). Redesain Injektor Udara Pembakaran Pada Perajin Gamelan Bali di Desa Tihingan. Jurnal Energi dan Manufaktur Vol, 6(2), 95-205.

Putri, P. D. W., \& Griadhi, I. P. A. (2015). Perbaikan Stasiun Kerja Menurunkan Aktivitas Listrik Otot dan Keluhan Muskuloskeletal pada Perajin Ukir Kayu di Desa Batuan Gianyar Bali. Jurnal Universitas Udayana. Fakultas Kedokteran.

Rolles, P., Manuaba, A., Adiputra, N., \& Pangkahila, A. (2009). Model Aktivitas Praktikum Lapangan Berbasis Ergonomi (Apelerg) Memperbaiki Respon Fisiologis Tubuh, Menurunkan Kelelahan, Dan Meningkatkan Kinerja, Dibandingkan Dengan Model Lama (Apel), Pada Mahasiswa FMIPA Unima. Indones J Biomed Sci, 3(1).

Salter, J. D., \& Wyatt, N. P. G. (1991). Sorting in the minerals industry: past, present and future. Minerals Engineering, 4(7-11), 779-796. https://doi.org/10.1016/0892-6875(91)90065-4

Saruta, K., Hirai, Y., Tanaka, K., Inoue, E., Okayasu, T., \& Mitsuoka, M. (2013). Predictive models for yield and protein content of brown rice using support vector machine. Computers and electronics in agriculture, 99, 93100. https://doi.org/10.1016/j.compag.2013.09.003

Setiawan, H. (2014). Desain Lingkungan Kerja Industri Karet Berbasis Ergonomi Guna Reduksi Beban Kerja Dan Peningkatan Produktivitas. Jurnal Teknologi, 7(1), 29-37.

Suarbawa, I. K. G. J. (2022). The rice sort machine design to improve rice granules quality. International Research Journal of Engineering, IT \& Scientific Research, 8(1), 17-26.

https://doi.org/10.21744/irjeis.v8n1.2045 
Soedibyo, D. W., Subrata, I. D. M., \& Ahmad, U. (2006). Pemutuan Edamame Menggunakan Pengolahan Citra dan Jaringan Syaraf Tiruan. Jurnal Keteknikan Pertanian, 20(3).

Sofi'i, I., \& Astika, I. W. (2005). Penentuan Jenis cacat Biji Kopi dengan Pengolahan Citra dan Artificial Neural Network.

Suarbawa, I. K. G. J., Arsawan, M., Yusuf, M., \& Santiana, I. A. (2018). Improvement of environment and work posture through ergonomic approach to increase productivity of balinese kepeng coin workers in Kamasan village Klungkung Bali. In Journal of Physics: Conference Series (Vol. 953, No. 1, p. 012105). IOP Publishing.

Suriani, N. L. (2019). Piper caninum blume leaf extract and compost to suppress blast disease and increase the production of bali red rice (oryza sativa) in green house. International Research Journal of Engineering, IT \& Scientific Research, 5(4), 46-54. https://doi.org/10.21744/irjeis.v5n4.693

Susana, I. G. B. (2018). Improve of worker performance and quality of anchovy with ergonomic hybrid solar dryer. ARPN Journal of Engineering and Applied Sciences, 13(5), 1662-1667.

Van Soest, P. J. (2006). Rice straw, the role of silica and treatments to improve quality. Animal Feed Science and Technology, 130(3-4), 137-171. https://doi.org/10.1016/j.anifeedsci.2006.01.023

Xie, Y., Szeto, G., \& Dai, J. (2017). Prevalence and risk factors associated with musculoskeletal complaints among users of mobile handheld devices: A systematic review. Applied ergonomics, 59, 132-142. https://doi.org/10.1016/j.apergo.2016.08.020

Yadnya, T. G. B., Trisnadewi, A. A. A. S., Sukada, I. K., \& Oka, I. G. L. (2016). The effect of offered diet containing rice hull and mono sodium glutamate (msg) and effective microorganism -4 (em-4) solution on the performance of campbell duck. International Research Journal of Engineering, IT \& Scientific Research, 2(11), 75-82. Retrieved from https://sloap.org/journals/index.php/irjeis/article/view/523

Yusuf, M., Santiana, M., \& Lokantara, W. D. (2018, May). Improvement of work posture to decrease musculoskeletal disorder and increase work productivity jewelry worker in bali. In Proceedings (Vol. 1, No. 1, pp. 242-247). 